\title{
God at work: An exploration of the dynamic inter-relationship between the reign of God and the people of God
}

\author{
Langerman, Peter \\ Stellenbosch University \\ peter@dpc.org.za
}

\begin{abstract}
In this article, it is argued that we must take seriously the missional invitation of the Triune God to communion and fellowship. Further, it is argued that it is this invitation which informs, shapes and forms the nature of our understanding of the missio Dei. The expression of the missio Dei is most clearly and visibly demonstrated in terms of the metaphor of the kingdom, the reign of God. It is the reality of the reign, the kingdom of God that creates a community, the ecclesia, the church. If we are to take seriously the link between the nature of God and the missio Dei and the link between the missio Dei and the kingdom, and the link between the kingdom and the community that the kingdom calls into being, then we must ask ourselves what the nature of that community should be. Ultimately, the community that derives its nature from the Trinitarian nature of God should have a specific shape and form and act in a certain way and it can be expected that those who act as leaders in this community should act in a certain way.
\end{abstract}

\section{Keywords}

Missio Dei, Kingdom of God, Rule and reign of God, Eschatology, Koinonia, People of God, Servant leadership

\section{Introduction}

As this article seeks to connect the implications of the coming of the reign of God and its implications for missionality, and the faith community, it is important to begin by examining how the concept of the missio Dei relates to the metaphor of the kingdom of God. Thereafter some of the implications that the reality of the kingdom-among-us has for the shape of the faith community, the community that is formed by the reality of the kingdom- 
among-us and for leadership within that community, will be examined. The relationship between the concept of the kingdom of God, which described the mission of Jesus in the canonical Gospels, and the more recent concept of the missio Dei is of the utmost importance for the contemporary church. As Bevans and Schroeder (2004:285) have pointed out, our understanding of mission in the present age is undergoing a radical review, becoming both

...much more modest and much more exciting - and indeed more urgent. It is more modest because we realize that the mission is not ours but God's; it is much more exciting because it is about God's gracious invitation to humanity to share in the dynamic communion that is at the same time God's self-giving missionary life ... But [mission] is prophetic dialogue because it calls people beyond; it calls to conversion; it calls people to deeper and fuller truth that can only be found in communion with dialogue's Trinitarian ground [sic]... modelled after mission in Christ's way of humility and self-emptying and bold proclamation of God's 'already' and 'not yet' reign.

\section{The nature of God and the missio Dei}

The conscious link between the nature of God and the mission of God is a relatively recent development ${ }^{1}$ and it was this link that established a new direction and paradigm in the history of missions and missiology, in which mission was located in, and derived from, the very nature of God. It is only during the last sixty years or that mission has come to be understood not in cultural, ecclesiological or soteriological terms, but, primarily, in

1 The origins of this link between the nature of God and the mission of God are contested. Bosch (1991:389-390) argues that it was at the Brandenburg Missionary Conference that '...Karl Barth became one of the first theologians to articulate mission as an activity of God himself... and [in] (1933) Karl Hartenstein gave expression to a similar conviction'. Bosch continues by arguing that this Barthian influence was strongly influential in establishing a new missiological paradigm that '...broke radically with the Enlightenment approach to theology [and] ...reached a peak at the Willingen Conference of the IMC (1952) [where] ...the idea (although not the exact term) missio Dei first surfaced clearly.' Contra Flett (2010:12) who claims 'In reality, Barth never once used the term missio Dei, never wrote the phase, 'God is a missionary God' and never articulated a Trinitarian proposition of the kind expressed at Willingen. No textual evidence indicates that Barth interacted with the missiological discussions that were engaged with his theology.' 
terms of flowing from the very communal nature of the Triune God. Bosch (1991:390) states that it was during this time that ' $[t]$ he classical doctrine on the missio Dei as God the Father sending the Son, and God the Father and the Son sending the Spirit was expanded to include yet another movement': Father, Son and Holy Spirit sending the church into the world.' As Bosch goes on to show, the emphasis in the Willingen Conference was on our participation in the sending action of God. However, to guard against this participation and partnership being understood in triumphalist terms, the conference '... recognized a close relationship between the missio Dei and mission as solidarity with the incarnate and crucified Christ.' Bosch (1991:391) then explains the missio Dei concept in the following terms:

In the new image, mission is not primarily an activity of the church, but an attribute of God. God is a missionary God... Mission is thereby seen as a movement from God to the world; the church is viewed as an instrument for that mission... There is church because there is mission, not vice versa... To participate in mission is to participate in the movement of God's love toward people, since God is a fountain of sending love.

If it is true that the Christian God is a missionary God, then it must follow that mission which is authentic and Christian, must be based on the mission of the Triune God, a mission which begins with the creation of the world and continues in the coming of Jesus Christ and will be completed by the Spirit at work within the church and, through the church, to the entire creation. Bosch (1991:81) concludes that ' $\mathrm{t}$ ] o meet Christ is to be caught up in a mission to the world.'

\section{The link between the missio Dei and the kingdom of God}

The realisation that the very nature of God implies that God has a missionary purpose raises questions about the ways in which God's desire that human beings should participate in making God's name known to all of creation become actualised. If it is God's desire for human beings to be involved in God's mission, then what are the means by which human beings are actually drawn into fulfilling this desire? Can we make a connection between the missio Dei and the metaphor of the kingdom of God? In this regard Hedlund (1991:74) has stated that '[t]he missio Dei concept has 
much in common with the kingdom of God motif.' After noting that the kingdom of God has sometimes been confined to social service and social transformation, Hedlund, in quoting Vicedom, argues that the kingdom of God is 'the goal of the missio Dei' and then continues by stating that '...this envisions a society of the redeemed [which] is not identical with a reconstructed social order, though this may well be one of the demands of seeking God's kingdom and His righteousness.' In order to asses if Hedlund is correct it is therefore necessary to reflect on how the kingdom of God should be understood.

\section{The kingdom of God: The rule of God, the reign of God and the people of God}

As shall be pointed out below, while there might be some dispute about what the kingdom meant - and means - what is not in dispute is that when John the Baptist first appeared, he preached that the kingdom of God was at hand and when Jesus began his ministry he preached that the time was fulfilled and that the kingdom of God was at hand. Ladd (1964:107) makes the point that, although there seems to be congruency between the messages of John the Baptist and Jesus, there is a greater sense of urgency in the teaching of Jesus about the kingdom than there was for John: 'Jesus asserted that the visitation was in actual progress, that God was already visiting his people. The hope of the prophets was being fulfilled.' Bosch (1991:31-32) points out that '[t]he reign of God...is undoubtedly central to Jesus' entire ministry. It is, likewise, central to his understanding of his own mission. One may say that, for Jesus, God's reign is the starting point and context for mission.' Ladd (1993:101-102) writes 'The kingdom does not come as men and women receive it. The ground of the demand that they receive the kingdom rests on the fact that in Jesus the kingdom has come in history. God has done a new thing. He has visited his people in Jesus' mission, bringing them the messianic salvation.' Bosch (1979:6) states that '[i]n the person of Jesus the Kingdom was present among men, yet they were unable to recognise it.'

2 Metts (2004:56) in his well-reasoned and thorough article, points out that '...[n] ever is it said in the New Testament that people can build or erect the kingdom, but they can enter it (Mt 5:20; 7:21; Mk 9:47; 10:23). Nowhere does the New Testament teach that people can establish the kingdom, but they possess it (Mt 5:4), inherit it (Mt 25:34), 


\subsection{The eschatology of the kingdom}

The means by which the Trinitarian God extends an invitation to human beings into communion and fellowship is in the person of Jesus Christ. Jesus was sent by the Father and anointed by the Spirit to make Yahweh known to people, to complete the self-revelation of God to human beings. Jesus came announcing the coming of the reign of God and demonstrating what that reign should, and would, look like in fulfilment of the Jewish prophecies. Wright (2012:112) argues that the Gospels indicate that 'Jesus came...to rescue and renew [the people of Israel] not to destroy it and replace it with something else. Israel is to be fulfilled, not replaced.' That invitation to fellowship and communion and the coming of the reign of God led to the creation of a kingdom people who took what Jesus had started and continued to extend it into what it was to become: nothing less than an on-going act of complete social transformation. Hans Küng (1968:43) points out that Alfred Loisy's famous statement 'Jesus proclaimed the Kingdom of God, and what came was the Church' is almost always quoted in the negative, whereas Loisy intended it positively.

The church, as that kingdom community and agent of social

transformation, continues to be governed, guided by and determined

by the reality of the reign of God, the kingdom-among-us.

There have been many different understandings about what the phrase, 'kingdom of God' actually means, made more complicated by the fact that while both John the Baptist and Jesus use the phrase extensively, neither explain what they understand by the concept. The kingdom of God to which both John and Jesus refer is eschatological - which Küng (1968:48) argues means that 'the fully realized final and absolute reign of God at the end of time which as an event is now 'at hand'... it has now come upon you'... 'it will come'...'with power'... Accordingly, Hans Küng

and receive it (Mk 10:15; Lk 18:17). Although they cannot destroy the kingdom, they can refuse to receive it (Lk 10:11) or enter it (Mt 23:13). They cannot bring the kingdom though they can seek it (Mt 6:33; Luke 12:31), pray for its coming (Mt 6:10) and look for it (Lk 23:51). Never is it stated that people act upon the kingdom, but things can be performed for the sake of the kingdom (Mt19:12; Lk 18:29). The kingdom may be preached (Mt 10:7; Lk 10:9), but only God can give it to people (Mt 21:43; Lk 12:32) who, in turn, cannot give it to one another nor take it away from one another. The kingdom of God can appear (Luke 19:11), be active (Mt 11:12), arrive (Mt 12:28), draw near (Mk 1:15; Mt3:2; 4:17) and it can come (Mt 6:10; Luke 17:20).' 
succinctly summarizes the various ways people have of understanding the phrase, dependent, to some extent, upon the eschatological position they take. Küng points out that there are various views on what the kingdom meant for Jesus and what it may mean for people today. According to Küng (1968:46) in the 'consistent eschatology of Schweitzer, the phrase held great meaning for Jesus and his contemporaries, as a 'universal catastrophe along the lines of Jewish apocalyptic thinking and hence no longer meaningful for us today' On the other hand the view of 'realized eschatology' holds that the kingdom of God was a present reality for Jesus and therefore is a reality for us too.' According to Bultmann's 'existential eschatology', the 'cosmic and apocalyptic expectations of a future event must be demythologized since they are no longer meaningful for us today.' Finally, there is the 'salvation-historical eschatology' which holds that 'the kingdom of God came with Jesus, but is still awaiting its fulfilment.' Hunter (1973:94) calls this an 'inaugurated eschatology' which means,

... the kingdom of God is not some moral dispensation in the heart of man, neither is it some Christian Utopia to be reared on earth by human endeavour; it is power breaking in on men from without through the direct and personal action of God. It is God himself intervening on the stage of history to 'visit and redeem his people.'

Inaugurated eschatology most accurately defines the nature of the kingdom both in the ministry of Jesus while on earth and after his ascension.

\subsection{Jesus and the kingdom of God}

Saucy (1997:21-22) points out that by the mid 1960's there was an emerging consensus that ' $[\mathrm{t}] \mathrm{he}$ amassed evidence was seen as pointing to the kingdom having multiple temporal dimensions. In some way it was present with Christ and in some way it was still future. ... [In 1985], I[an] Howard Marshall has noted no change in the consensus of the present or fulfilled and future or consummation position.'

Hunter (1973:92) asks what the concept of the kingdom of God might have meant for a Jew alive at the time of Jesus. He suggests that it could have referred to one of three concepts: the eternal sovereignty of God; the covenantal relationship of God with Israel and the divine intervention of God in the life of the nation of Israel and he draws these three concepts together in the following way, 'The eternal sovereignty, now acknowledged 
in Israel, will one day be effectively manifested in the world.' Wright (1999:35) also asks what Jesus, and his hearers, might have understood about the message of the kingdom. Wright answers this question by means of reference to '...election and eschatology: God's choice of Israel to be the means of saving the world; God's bringing of Israel to its moment of crisis, through which justice and mercy would embrace not only Israel but the whole world.'

Newbigin (1995:52) writes about the nature of the kingdom community:

... [T] here is a society in which the life of the crucified and risen Jesus lives on and his mission continues, not only as the proclamation of the kingdom, but as the presence of the kingdom in the form of death and resurrection... The presence of the kingdom, hidden and revealed in the cross of Jesus, is carried through history hidden and revealed in the life of the community which bears in its life the dying and rising of Jesus

The coming of the Messiah, his death and resurrection, fulfilled Jesus' mission of bringing the kingdom of God to earth. Yet, we still live within the tension of the 'already' and 'not yet'. The reality of this tension challenges the church again today to listen for other voices to which to listen, to help us to read the signs of the times and interpret the events around us. Wright (1999:12) argues that the kingdom-among-us should continue to set the agenda for the kingdom community, the church:

Just as integrity demands that we think rigorously about Jesus himself, so it also demands that we think clearly about the world in which we follow him today, the world we are called to shape with the loving transforming message of the gospel. It challenges us to tell God's good news to the world. It remains the calling of the church today.

Modernism has created a space where believers thought they could make sense of Jesus' life, work and ministry as long as they had enough knowledge about Jesus. However, Wright argues, believers cannot simply attempt to derive knowledge about Jesus from their own perspective, but must attempt to understand how Jesus functioned in his own time and context. Christians, therefore, must go back to the living world in which Jesus lived and allow him to reveal himself to them in a fresh and 
new way. This approach represents a move beyond modernism so that revelation about Jesus does not leave Christians unchanged. Like the early church, Christians are challenged to bring the revealed Jesus into their communities. The Father sent Jesus, the Father and the Son send the Spirit and the Trinity sends the church - this is our on-going call to mission.

But like the early church, the church still struggles every day with what this means and that is the challenge that Jesus presents to the contemporary church. God works through the church to reach the world, the work that Jesus began has been entrusted to the church to continue in the power of the Spirit. In this regard, Newbigin (1988:34-36) states that the church is a foretaste of the kingdom because it celebrates as a reality that which the world calls an illusion; it is an instrument of the kingdom because it is the means by which God's will for justice, peace and freedom is demonstrated in the world and it is a sign of the kingdom because it points people toward that unseen reality.

It would not be wrong to assert that any attempt to understand the dynamic nature of the kingdom of God, the reign of God, must begin with some understanding of the processes taking place in the world and history as the actions of God's redemptive word at work: the act in which God, according to Barth (Barth 1949:68) '...from all eternity willed to become man in Jesus Christ for our good, did become man in time for our good, and will be and remain man in eternity for our good'

\subsection{Fulfilment without consummation: The already but not yet}

Ladd (1964 \& 1974) was one of the first to help us understand the processes of the kingdom, the reign of God, in both the Hebrew Scriptures and the New Testament. Ladd's (1964:135) central thesis regarding the kingdom of God is that the kingdom is the dynamic power of the reign of God at work in the world and that God has manifested this reign in the person and mission of Jesus. He argues that prior to the eschatological and apocalyptic coming of the kingdom, God's kingdom has already become dynamically active in the world in Christ.

So, Jesus comes preaching and demonstrating the coming of the kingdom of God. But, in the coming of Jesus, the kingdom of God came without bringing an end to the present age. The kingdom came, but in an unexpected way, the kingdom promise was fulfilled but not consummated. 
As early as 1954, CH Dodd (1954:16) argued that Jesus' self interpretation of his mission was that it was nothing less than that point of crisis whereby the long awaited kingdom of God made its appearance on earth. That crisis began at his birth; it was complete at his resurrection and ascension. The ascended Christ had become nothing less than the invisible king of the world.

The kingdom is thus the action of God's dynamic rule and reign upon the earth. The contemporary church lives in the time of the overlap, in the time when the future glory of the kingdom of God has been realized in principle in history, but still awaits its ultimate consummation. We thus live in the presence of the future, and in the time when the kingdom is already here in that Jesus has won the victory over the evil one, but the final victory has not yet been realized. ${ }^{3}$

In the light of an inaugurated eschatology, we may thus talk of the kingdom of God as the presence of the future ages within the present age. The coming of the kingdom of God means that the Hebrew Scripture prophecies about the coming of God's kingdom are fully fulfilled in Christ. Through his birth, life, sufferings, death, resurrection and ascension, the power and authority of the future are present with us, but not yet fully consummated.

\subsection{Implications of the presence of the future}

\subsubsection{The goal and purpose of history has been realized}

There are certain implications to the reality of the kingdom-among-us. In the first place, the goal and purpose of creation has been realized in principle in history. Hunter (1976:50) points out that in this emerging kingdom that Jesus proclaimed

[t]he king...was a Father...God's Fatherhood was therefore a secret he disclosed to his own chosen followers in private. And if we ask why, the answer is, because the experience of God as Father was the last reality - the deepest secret - of his own spiritual life... Only with the coming of the Holy Spirit did Jesus' secret become an open secret.'

3 Metts (2004:57) refers to these tensions as 'eschatological-historical tensions' and defines them as 'already-not yet; fulfilment-consummation; promise-fulfilment; realistic futuristic; this age-age to come... The foundation to understanding how the kingdom of God can be both present and future...' 


\subsubsection{A new age of salvation}

A second implication is that because of the realities mentioned above, a new age of salvation has dawned. The life - eternal life - the peace, the joy, the forgiveness, the righteousness of heaven is available right here and now for those who believe.

This, suggests Wright (2012:196), is the crux of the Gospels' theology of atonement: 'God himself will come to the place of pain and horror, of suffering and even death, so that somehow he can take it upon himself and thereby set up his new style theocracy at last.'

\subsubsection{Satan decisively defeated}

A third implication according to the writings of the New Testament is that Satan has been decisively defeated. This process begins during the life of Jesus and is finally accomplished on the cross. Ladd (1964:148) writes 'This conquest over Satan by the power of the kingdom of God is accomplished in this age, before the coming of the eschatological Kingdom....The figures of the binding and disarming of Satan are metaphors describing a spiritual reality.' Since the resurrection and ascension of Jesus and the outpouring of the Holy Spirit, there is not an on-going battle for the defeat of evil represented by the principalities and powers, but the church is called to enforce the victory that was won by Christ on the cross. Bosch (1979:7) writes that '...the enemy is still active in God's world, extremely active, but we should never allow ourselves to accept that this world belongs to the enemy... let us never for one moment forget that [Satan is]...a usurper.'

\subsubsection{The kingdom creates a new community}

The fourth implication is that the kingdom creates a new community. Although Jesus' primary purpose in coming to earth was to establish the kingdom of God, we cannot lose sight of the role and function of the kingdom community, the church. How does the kingdom of God relate to the church of Jesus Christ? How do they fit together?

Dulles (in Saucy 1997:280) notes the relationship that the reality of the reign of God has upon the faith experience of Christians because it is through faith that Christians come to participate in the life of the kingdom. It is through this faith-driven participation in the kingdom that Christians become agents of justice and bearers of power. 
As Ladd (1964:259-260) points out, the New Testament makes it clear that the church is not the kingdom. The kingdom refers to the universal rule and reign of God that extends throughout time, space and history. The church, as we have seen earlier, is the foretaste, the instrument and the sign of the kingdom, the one called to bear witness to the kingdom and to invite people to enter the kingdom.

Jesus' mission on the earth was to bring the kingdom of God and not to establish the church, but, as Ladd (1964:261) argues, the processes that are released through the coming of the kingdom, establish a new basis of fellowship. Those who met Jesus and whose lives were radically changed by meeting with him were usually the poor, the outcast, the sinners, the broken and the sick, those who recognized their need.

Hunter (1976:50-51) points out that the kingdom of God carries with it the implication that there should be those who live submitted to God's divine rule that the kingdom brings. Specifically, Jesus called and taught the twelve as the new Israel, sent them out as messengers of the kingdom and, in the Last Supper, established the church.

Newbigin (1995:52) argues that just the coming of the kingdom was hidden by the cross of Christ, so the reign of God is present, albeit obscured, in the community that the kingdom creates; a community that bears Christ's name and shares Christ's mission.

Jesus' primary purpose was to offer the kingdom to the Jewish people, but in a way that they did not expect. They expected that the kingdom would be primarily a political and social kingdom that would liberate the Jewish people from oppression under the Romans, but Jesus offered them a spiritual kingdom which was the opposite of what they expected. The Jewish religious and political leaders rejected the offer that Jesus made to them, and so he put the kingdom in the hands of the small band of people that followed him. Jesus 'gave them the Kingdom'. The Gospels record for us the training by Jesus of his followers to be faithful custodians of the kingdom of God.

Speaking of the kingdom community, Bosch (1979:9) states that despite the weaknesses of the church, the church continues to occupy a unique position and quotes Oepke Noordmans in whose opinion, the church is 'too early for heaven and too late for the earth.' 
Wright (2012:198) points to the way in which the reality of the suffering and death of Christ, and the resurrection of Christ, as well as the coming of the Spirit, become the place where Christ established himself as the king of the kingdom of God, and transformed Israel as the renewed people of God. Jesus saw in the group with whom he lived in community the new 'fathers and mothers' of the kingdom of God. As God had established covenants with Noah, Abraham, Moses and David, so Jesus came to establish a new covenant that would signify a fresh start with these people. They were to model the characteristics of the kingdom community, the new people of God. ${ }^{4}$

Through the life in the Spirit, the experience of the power of the Holy Spirit, the values of the kingdom, Jesus was building his 'church', his 'ecclesia': his community of people called out from the world and bound to one another. His community would represent him on the earth and would be the primary place where the kingdom would be seen. The 'ecclesia' would be the earthly expression of the spiritual reality of the presence of the future. In the same way that Jesus came to bring the kingdom, so the church would model the kingdom community.

So, Wright (2012:202) argues, for the early church suffering, misunderstanding and even death were seen as part of the vocational reality of those who followed as Christ's disciples. The New Testament vision of the church is, according to Wright, something which 'grows directly out of the vision of God's holy ones 'receiving the kingdom' in Daniel 7. But it does so insofar as, and only insofar as, the category of the 'holy ones' is shrunk right down to the one man, Jesus himself and opened up thereafter to his followers.'

Remembering that the very nature of Godself is our basis for understanding the missio Dei and that the article has argued that the missio Dei is expressed through the ministry of Jesus as the coming of the kingdom, it is necessary to ask, 'What should the 'church' look like? What are the characteristics of the true Kingdom community?' It must reflect something

4 Bosch (1979:9) quoting the Heidelberg Catechism and the Belgic Confession, writes '... the church is the community of believers, gathered by divine election, calling new birth, and conversion, which lives in communion with the Triune God, is granted forgiveness of sins, and is sent to serve the world in solidarity with all mankind.' 
of the communal nature of the Godself that Christians confess in the Trinity since it is the expression of those who have responded to God's invitation to be in community with God.

\subsection{Koinonia as the basis of the kingdom community}

The faith community is a family. Hunter (1957:31) states that ' $[w]$ hen we say that the dominant theme of Jesus' preaching was the Kingdom of God, we easily forget that the King of this Kingdom was a Father' and that 'the People of God is a necessary corollary of the Kingdom of God.'

The structure of the kingdom community was relationship not authority, and the relational base was love not compulsion: the community functioned on the basis of the rule of love and peace. Davey (2001:79), in stressing that the life of the 'ecclesia' (the elect) was built upon real koinonia (fellowship): sharing life together, eating together, and relating to one another at a very deep level, writes

[b]eyond the local gathering, the 'connectivity', the network of Christian communities, underpinned the impact of the gospel. They began to reflect upon, draw out, and implement the significance of the narratives and teachings they had come to know, not least working through the implications of the story of Jesus in the corporate lives of those it touched

Their resources (time, energy, money) were shared with the poor, the sick, the sinners and those on the margins of society.

As Davey (2001:70) points out, 'Through the declaration of God's new order ... and the re-imagining of Torah, Jesus intervenes in the false order that distorts and divides the people of God, and the processes that through de-valorisation create people who are outcasts and excluded.' Bosch argues (1979:11) that '[i]f the church is true to its function as a parable of the Kingdom, her special concern will be for those who are powerless...Jesus, too, was concerned about the victims of society; his entire ministry could be summarised in one word: 'compassion."

There was on-going persecution and conflict as well as proclamation of the good news of the gospel and demonstration of the presence of the kingdom. In this regard, Wright (2012:203) argues that the slaughtered and exalted 
Lamb of Revelation is not only the shepherd of the people called to follow him, ' ...but he is also their template. Sharing this suffering is the way in which they are to extend his kingdom in the world.'

So far it has been argued that we must take seriously the missional invitation of the Triune God to communion and fellowship and that it is this invitation which informs, shapes and forms the nature of our understanding of the missio Dei. As we saw, the missio Dei is expressed in terms of the metaphor of the kingdom, the reign of God and it is the kingdom of God that creates a community, the ecclesia, the church. If we are to take seriously the link between the nature of God and the missio Dei and the link between the missio Dei and the kingdom, and the link between the kingdom and the community that the kingdom calls into being, then we must ask ourselves what the nature of that community should be. If that community ultimately derives its nature from the Trinitarian nature of God, then that should have certain implications for the community itself.

\section{The shape and form of missional communities}

Communities that derive their existence from the presence of the kingdomamong-us, the reign of God, should exhibit certain characteristics. McKnight (2008:9) writes

The kingdom of God is more than what God is doing 'within you' and more than God's personal 'dynamic presence'; it is what God is doing in this world through the community of faith for the redemptive plans of God - including what God is doing in you and me. It transforms relationship with God, with self, with others, and with the world.

We may say with confidence, therefore, that the reality of the kingdomamong-us creates a community, a community that Volf (1996:50) reminds us is based upon '...the new world that God is creating, a world in which people from every nation and every tribe, with their cultural goods, will gather around the triune God, a world in which every tear will be wiped away and 'pain will be no more' (Rev 21:3).' This missionary God invites us, not only into communion and fellowship with God and with others, but also invites us to participate in God's mission. Responding to God's invitation means that believers are commissioned to invite others to 
respond in the same fashion. Breedt and Niemandt (2013:2) put it this way: 'The church is incarnational and as the body of Christ represents the missio Dei in any community and culture it finds itself in.' McKnight, (2007:119120) states that it is the work of the sanctifying Spirit who, in love, creates a community where people come to share in the life of one another. $\mathrm{He}$ $(2007: 121,122)$ argues that it was the gospel that restored brokenness in people so that they could, in turn, help to restore the brokeness of others. The Christian community became the place where justice prevailed, where the norm became healthy loving relationships and where the community showed compassion to the broader society.

\section{A journey into missional leadership and transformational leaders}

If this is something of the form of missional communities, what does it mean to be a leader in such a community? This is becoming an increasingly more urgent question since the rise of the emerging church movement and the questions that are being posed by this challenge to the established church. While the specifics of the emerging church movement are beyond the scope of this article, Robert Doornebal in his excellent book, 'Crossroads' (2012) explores the nature of the emerging church movement and the implications for the concept of missional leadership. Doornebal (2012:200) defines missional leadership in the following way:

Missional leadership refers to the conversational processes of envisioning, cultural and spiritual formation, and structuring within a Christian community that enable individual participants, groups, and the community as a whole to respond to challenging situations and engage in transformative changes that are necessary to become, or remain, oriented to God's mission in the local context.

Doornebal (2012:201-202) explains that the phrase 'conversational processes' emphasises the role that leaders play in guiding all people in the organization to play a part in shaping the future of that organization in both formal and informal ways. He acknowledges that even in the emerging church movement there is an emphasis on leadership, but that this emphasis is on leadership that takes place together with others and not in isolation, through 'conversational processes. Ellison (2009:169), 
writing about just these types of conversations, argues '...decisions must be shared by the largest possible number of participants and that calls for a group conversation process that will involve talking with God and with one another until a decision and an action emerge.'

According to Robinson (2008:84): 'Leadership is mobilizing a congregation (be it small or large) to engage its own most pressing problems and deepest challenges.' Accordingly, I would say that my understanding of a missional leader is of someone who is committed to seeking, along with others, to know what God is up to in our midst in order to discover what Kiefert calls our 'preferred and promised future'.

Osmer (2008:176-177) details three kinds of leadership. The first he calls 'Task Competence' and this he describes as '... the ability to excel in tasks of a leadership role in a congregation.' The second he calls 'Transactional Competence' which he describes as

... the ability to influence others through a series of trade-offs ...

[which] takes place in two basic ways: (1) meeting the needs of those involved in the organization in return for their contribution to the organization and (2) making political trade-offs to compete with competing agendas of different coalitions in an organization so that it can best accomplish its objectives.

The third type of leadership he calls 'Transformational Leadership', which he argues involves 'deep change' and he describes this leadership model as involving '.. leading the organization through a process in which its identity, mission, culture and operational procedures are fundamentally altered.'

Doornebal (2012:203) explains the words 'envisioning', 'formation' and 'structuring' by reference to Philip Selznick's three-fold description of leadership tasks:

(1) defining the organization's mission and role (this might be called envisioning); (2) embodying that purpose in its organizational life (this refers to structuring), and (3) helping the organization and its members give expression to their distinctive values in the face of threats, from both within and without (this has to do with cultural and spiritual formation). 
Of the three functions mentioned by Doornebal (2012:205), the one that most concerns us here is the first, which he defines as envisioning: '...which can be interpreted as a communally exercising of theological imagination and discernment, in which Bible study and prayer play a crucial role, in order to discern the identity and calling of the congregation.'

McKnight (2007:138) writes, 'In Matthew 12:15-21, the first evangelist is clear in presenting the ministry of Christ the Messiah as the embodiment of the suffering servant of Isaiah.' Since the ministry of Christ adheres so strongly to the suffering servant of Isaiah, it follows that those who lead in Christ's name must, at least, take that 'suffering servant' image seriously. This leads Osmer to discuss the concept of servant leadership. This concept of leadership is, Osmer (2008:189) suggests, informed, and determined by, Christ's role as the servant:

Paul's use of the Servant Songs of Isaiah to portray Christ's royal rule represents nothing less than a reversal of the way power is conventionally understood ... [P]ower pre-eminently is selfgiving love in which the needs of others and the community take precedence.

Osmer's (2008:190) definition of servant leadership is '... leadership that influences the congregation to change in a way that more fully embody the servanthood of Christ.' Servant leaders will give power away and appreciate that '... [1]eaders gain power by empowering others' (Osmer 2008:198).

Leading on from this, in their recent insightful and interesting article, Breedt and Niemandt, using the relationship of the Trinity as a base, argue for a concept which they call Relational Leadership (RL). After saying (2013:4) that 'Relational Leadership is closely related to servant leadership, but with the focus on relationships rather than serving,' the authors go on to define Relational Leadership in the following terms:

RL refers to a model or perspective on leadership that focuses on the idea that effective leadership has to do with the ability of the leader to create positive relationships within an organisation. As this definition indicates, RL has the power to unleash the potential of the individual together with that of the organisation through relationships. The reality of the relational world we live in demands a leadership strengthened with relationships.' 
Although a full analysis of this article is beyond the scope of this work, it is submitted that Relational Leadership complements the transformational leadership I have argued for in this work.

\section{Conclusion}

In this work we have sought to paint a picture of a community that takes seriously the reality of the kingdom-amongst-us and whose life and existence derives directly from the reality of the life within the Trinity. We have argued that such a community has a specific shape and form, which we might identify as 'missional' - responding to the invitation that comes via the missio Dei to work with God and inviting others to join with them. Since such communities have a specific shape and form, they are served by a special kind of leader, a servant leader.

\section{Works cited}

Barth, K 1949 Dogmatics in Outline. London and Southhampton: The Camelot Press.

Bevans SB \& Schroeder RP 2004. Constants in Context: A Theology of Mission for Today. Maryknoll, NY: Orbis Books.

Bosch, DJ 'The Kingdom Of God And The Kingdoms Of This World.' Journal of Theology for Southern Africa 29 (1979): 3-13.

- 1991. Transforming Mission: Paradigm Shifts in the Theology of Mission. New York: Orbis Books.

- 1991. 'Witness to the World.' In Perspectives on the World Christian Movement : A Study Guide, 78-82. Pasedena: William Carey Library.

Breedt, JJ \& Niemandt, CJP 'Relational Leadership and the Missional Church.' [Online]. Verbum et Ecclesia 34 (1) Art \#819, 9 pages.

3 October 2013. Available: http://dx.doi.org/10.4102/ve.v34i1.819 [Accessed Mar 7, 2014].

Davey, A 200. Urban Christianity and the Global Order: Theological Resources for an Urban Future. Londo: SPCK. 
Dodd, CH 1954. The Coming of Christ. 2nd Edition. Cambridge: Cambridge University Press.

Doornebal, R 2012. Crossroads: An Exploration of the Emerging Missional Conversation with a Special Focus on 'Missional Leadership' and its Challenges for Theological Education. Delft: Eburon Academic Publisher.

Flett, JG 2010. The Witness of God: The Trinity, Missio Dei, Karl Barth, and the Nature of Christian Community. Grand Rapids: William B Eerdmans.

Hedlund, RE 1991. The Mission of the Church in the World: A Biblical Theology. Grand Rapids, Michigan: Baker House Books.

Hunter, AM 1957. Introducing New Testament Theology. Norwich: SCM Press.

- 1976. Jesus: Lord and Saviour. London: SCM Press.

- 1973. The Work and Word of Jesus. Revised Edition. London: SCM Press.

Kiefert, PR 2006. We Are Here Now: A New Missional Era (A Missional Journey of Spiritual Discovery). Eagle, Idaho: Allelon Publishing.

Küng, H 1968. The Church. London: Search Press.

Ladd, GE 1972. A Commentary on the Revelation of John. Grand Rapids: William B Eerdmans.

- 1993. A Theology of the New Testament. Rev ed (ed Donald A Hagner). Grand Rapids: Eerdmans.

- 1964. Jesus and the Kingdom: The Eschatology of Biblical Realism. Waco, Texas: Word Books.

- 1968. The Pattern of the New Testament. Grand Rapids: Eerdmans.

- 1974. The Presence of the Future: The Eschatology of Biblcal Realism. Grand Rapids: Eerdmans.

McKnight, S 2007. A Community Called Atonement. Nashville: Abingdon Press.

Metts, HL 'The Kingdom of God: Background and Development of a Complex Discourse Concept.' Criswell Theological Review 2, no. 1 (Fall 2004) (2004): 51-82. 
Newbigin, L 1961. A Faith for this One World. London: SCM Press.

- 1988. 'On Being the Church for the World.' In The Parish Church? Explorations in the Relationship of the Church and the World, edited by G Ecclestone, 25-42. Oxford: Mowbray.

- 1989. The Gospel in a Plaralist Society. Grand Rapids: William B Eerdmans.

- 1995. The Open Secret: An Introduction to the Theology of Mission. Revised. Grand Rapids: William b Eerdmans.

- 1963.The Relevance of Trinitarian doctrine for Today's Mission. CWME Study Pamphlets No 2. London: Edinburgh House Press.

Osmer, R 2008. Practical Theology: An Introduction. Grand Rapids: Eerdmans.

Robinson, AB 2008. Changing the Conversation: A Third Way for Congregations. Michigan: William B Eerdmans.

Saucy, M 1997. The Kingdom of God in the Teaching of Jesus in $20^{\text {th }}$ Century Theology. Dallas: Word Publishing.

Volf, M 1996. Exclusion \& Embrace: A Theological Exploration of Identity, Otherness, and Reconciliation. Nashville: Abingdon Press.

Wright, CJH 2006. The Mission of God: Unlocking the Bible's Grand Narrative. Downers Grove: Inter Varsity Press.

Wright, NT 2012. How God Became King: The Forgotten Story of the Gospels. New York: Harper Collins.

- The Challenge of Jesus: Rediscovering who Jesus was and is. London: SPCK. 